\title{
Effectiveness of Rapid Urease Diagnostic Test in Diagnosing Helicobacter Pylori Infection in Patients with Dyspepsia in Gastrointestinal Endoscopy Centre
}

\author{
Hasan Maulahela, Ari Fahrial syam, Murdani Abdullah \\ Division of Gastroenterology, Department of Internal Medicine, Faculty of Medicine \\ Universitas Indonesia/Dr. Cipto Mangunkusumo General National Hospital, Jakarta
}

\begin{abstract}
Corresponding author:
Hasan Maulahela. Division of Gastroenterology, Department of Internal Medicine, Dr. Cipto Mangunkusumo General National Hospital. Jl. Diponegoro No. 71 Jakarta Indonesia. Phone: +62-21-3153957; Facsimile: +62-21-3142454. E-mail: hasan.maulahela@yahoo.com
\end{abstract}

\begin{abstract}
Background: Diagnosis of H. pylori infection is important in patient with dyspepsia. There are several methods in the diagnosis of $H$. pylori infection. Histopathology is still the gold standard, but it requires more time and higher cost. Rapid diagnosis from biopsy sample using urease test has been developed to provide rapid on-site diagnosis. This study aims to obtain accuracy of rapid urease test in diagnosis of H. pylori.

Method: Patients with dyspepsia in Cipto Mangunkusumo National General Hospital who underwent esofagogastroduodenoscopy was included in this study. Biopsy sample was taken for rapid urease test using Helicotec and histopathology examination.

Results: Prevalence of H. pylori infection based on histopathology examination was 7.2\%. From seven positive results in histopathology examination, four samples were Helicotec positive. The sensitivity and specificity of rapid urease test using Helicotec was $57.1 \%$ and $98.9 \%$. The positive predictive value and negative predictive value were $80 \%$ and $96.7 \%$.

Conclusion: Rapid urease examination using Helicotec for H.pylori infection has a good accuracy, faster and cheaper. Interpretation of rapid urease test also need to consider clinical condition of patients who are tested.
\end{abstract}

Keywords: Helicobacter pylori, dyspepsia, rapid urease test

\footnotetext{
ABSTRAK

Latar belakang: Diagnosis infeksi H. pylori penting dilakukan pada pasien dengan dyspepsia. Terdapat berbagai metode diagnosis untuk infeksi H.pylori. Pemeriksaan histopatologi merupakan pemeriksaan gold standard namun memerlukan waktu lebih lama dan biaya yang lebih tinggi. Pemeriksaan yang lebih cepat dan murah telah dikembangkan dengan menggunakan rapid urease test. Penelitian ini bertujuan untuk menilai akurasi pemeriksaan rapid urease test (helicotec).

Metode: Penelitian ini dilakukan pada pasien dengan keluhan dyspepsia yang menjalani Tindakan esofagogastroduodenoskopi di Rumah Sakit Umum Pusat Nasional Cipto Mangunkusumo. Sampel biopsi diambil untuk pemeriksaan rapid ureae test (helicotec) dan histopatologi sebagai gold standard.

Hasil: Prevalensi infeksi H.pylori berdasarkan pemeriksaan histopatologi pada penelitian ini adalah 7.2\%. Sensitivitas dan spesifisitas pemeriksaan rapid urease test dengan helicotec adalah $51.7 \%$ dan $98.9 \%$. Positive predictive value dan negative predictive value adalah $80 \%$ dan $96.7 \%$.
} 
Simpulan: Pemeriksaan rapid urease test dengan helicotec memiliki akurasi yang cukup baik untuk diagnosis infeksi H.pylori. Interpretasi hasil pemeriksaan rapid urease test tetap memerlukan kesesuaian dengan klinis atau gambaran endoskopi.

Kata kunci: Helicobacter pylori, disepsia, rapid urease test

\section{INTRODUCTION}

Helicobacter pylori is one of the most important infectious agents in the world. These bacteria infect $50 \%$ of the world population. Gastritis due to $H$. pylori has been associated with the incidence of peptic ulcer, B cell primary lymphoma in the stomach, and gastric carcinoma. In dyspepsia, eradication of $H$. pylori helps symptoms improvement and treatment cost efficiency. ${ }^{1}$

Prevalence of $H$. pylori is quite high in less developed Asian countries, such as India, Bangladesh, Pakistan, and Thailand. A study in Jakarta found that the prevalence of $H$. pylori infection decreases from $12.8 \%$ in 1998 to $2.9 \%$ in 2005 . Several risk factors which have been associated with $H$. pylori infection include age, social economy class, geographical area (more H. pylori infected individuals in rural areas compared to urban areas), and several dietary factors. ${ }^{2,3}$ Among those factors, social economy class is an independent risk factor.

To date, the gold standard test to diagnose H. pylori infection is histopathology and culture examinations. However, considering its significant amount of preparation time, this method is not ideal for implementation in daily practice. Upon further development, other supporting examinations have been developed. One of those tests is through detection of urease enzyme from tissue biopsy. This method is faster in diagnosing $H$. pylori infection. Several urease tests which are commercially available in Indonesia include Helicotec and Pronto Dry.

Dyspepsia is defined as chronic or recurrent pain or discomfort sensation, centred around the upper region of the abdomen and if accompanied with predominant or often (more than once a week); heartburn or acid regurgitation need to be considered as gastroesophageal reflux disease (GERD) until proven otherwise. ${ }^{4}$ In dyspeptic patients, it was stated by McColl et al that patients with dyspepsia who are positively infected by $H$. pylori has the possibility of duodenal ulcer as much as $40 \%$ and gastric ulcer $13 \%$, while dyspepsia patients with negative $H$. pylori only has the possibility of duodenal ulcer of $2 \%$ and gastric ulcer of $3 \%{ }^{5}$

This study aimed to evaluate urease test in diagnosing $H$. pylori infection in dyspepsia patients. It is expected that we could obtain a scientific evidence which can become the basis of routine use of urease examination in diagnosing $H$. pylori infection.

\section{METHOD}

This study used diagnostic study design. This study was performed in adult dyspepsia patients who underwent endoscopy examination in Gastrointestinal Endoscopy Centre Cipto Mangunkusumo General Hospital in January - November 2018.

The inclusion criteria were dyspepsia patients, aged more than 18 years, and indicated to undergo upper gastrointestinal tract endoscopy. Exclusion criteria include patients who were pregnant or breastfeeding, refused endoscopy examination, had contraindication to undergo endoscopy, had endoscopic results of gastric malignancy, or consumed antibiotics, nonsteroidal antiinflammatory drugs (NSAIDs), proton pump inhibitors in the previous 2 weeks.

Patients who fulfilled the inclusion criteria underwent endoscopic examination and biopsy samples were obtained from two points in the antrum and one point in the corpus. One biopsy sample was intended for rapid urease test using Helicotec which was performed according to the standard procedure and was interpreted 2 hours later. Biopsy for histopathological examination was preserved in formalin solution and sent to Histopathology Department for analysis and identification of $H$. pylori bacteria. Interpretation of histopathological examination of gastric biopsy sample was performed using Updated Sydney System Classification.

Statistical analysis was performed to obtain sensitivity, specificity, positive predictive value (NPV), negative predictive value (NPV), and likelihood ratio (LR). A p value $<0.05$ is considered as significant.

\section{RESULTS}

There were 97 patients participated in this study, comprising of $40(41,2 \%)$ male and $57(58,8 \%)$ female patients. Patients' age ranged from $20-85$ years with an average of 50,12 $\pm 15,30$. Other patients' characteristics were presented in table 1. Endoscopic results were shown in Table 2. 
Table 1. Patients' characteristics

\begin{tabular}{|c|c|}
\hline Characteristics & n (\%) \\
\hline \multicolumn{2}{|l|}{ Sex } \\
\hline Male & $40(41.2)$ \\
\hline Female & $57(58.8)$ \\
\hline \multicolumn{2}{|l|}{ Marital status } \\
\hline Married & $79(81.4)$ \\
\hline Unmarried & 18 (18.6) \\
\hline \multicolumn{2}{|l|}{ Religion } \\
\hline Buddhism & $4(4.1)$ \\
\hline Moslem & $64(66)$ \\
\hline Catholic & $2(2.1)^{\prime}$ \\
\hline Konghucu & $1(1)$ \\
\hline Christian & $26(26.8)$ \\
\hline \multicolumn{2}{|l|}{ Domiciled in } \\
\hline Jabodetabek & $89(91.8)$ \\
\hline Outside Jabodetabek & $8(8.2)$ \\
\hline \multicolumn{2}{|l|}{ Ethnicity } \\
\hline Acehnese & $1(1)$ \\
\hline Ambonese & $3(3.1)$ \\
\hline Arabian & $1(1)$ \\
\hline Bataknese & $26(26.8)$ \\
\hline Betawinese & $2(2.1)$ \\
\hline Javanese & $27(27.8)$ \\
\hline Lomboknese & $1(1)$ \\
\hline Manadonese & $1(1)$ \\
\hline Minangnese & $10(10.3)$ \\
\hline Palembangnese & $2(2.1)$ \\
\hline Sundanese & $14(14.4)$ \\
\hline Ternatenese & $2(2.1)$ \\
\hline Chinese & $7(7.2)$ \\
\hline \multicolumn{2}{|l|}{ Occupation } \\
\hline Labour & $1(1)$ \\
\hline Housewife & $39(40.2)$ \\
\hline Student & $2(2.1)$ \\
\hline Priest & $1(1)$ \\
\hline Retired & $9(9.3)$ \\
\hline Civil worker & $8(8.2)$ \\
\hline $\begin{array}{l}\text { Artist } \\
\text { Private }\end{array}$ & $2(2.1)$ \\
\hline $\begin{array}{l}\text { Private } \\
\text { Jobless }\end{array}$ & $\begin{array}{l}15(15.5) \\
7(72)\end{array}$ \\
\hline $\begin{array}{l}\text { JoDless } \\
\text { Entrepreneur }\end{array}$ & $11(11.3)$ \\
\hline \multicolumn{2}{|l|}{ Economy (Rupiah) } \\
\hline$<2,500,000$ & $38(39.2)$ \\
\hline $2,500,000-5,000,000$ & $50(51.5)$ \\
\hline $\begin{array}{l}>5,000,000 \\
\text { Toilet }\end{array}$ & $9(9.3)$ \\
\hline \multicolumn{2}{|l|}{ Toilet } \\
\hline $\begin{array}{l}\text { Private } \\
\text { Public }\end{array}$ & $96(99)$ \\
\hline \multirow{2}{*}{\multicolumn{2}{|c|}{ Source of drinking water }} \\
\hline & \\
\hline Mineral water & $80(82.5)$ \\
\hline Boiled water & $17(17.5)$ \\
\hline \multicolumn{2}{|l|}{ Soymilk consumption } \\
\hline Yes & $0(0)$ \\
\hline No & $100(100)$ \\
\hline \multicolumn{2}{|l|}{ History of endoscopy } \\
\hline $\begin{array}{l}\text { Yes } \\
\text { No }\end{array}$ & $30(30.9)$ \\
\hline
\end{tabular}

Jabodetabek: Jakarta, Bogor, Depok, Tangerang, Bekasi

Table 2. Results of endoscopic and histopathology examination

\begin{tabular}{ll}
\hline Characteristics & $\mathbf{n}(\%)$ \\
\hline Results of oesophagus endoscopy & \\
Normal & $41(42.3)$ \\
Grade A oesophagitis & $39(40.2)$ \\
Grade B oesophagitis & $8(8.2)$ \\
Grade C oesophagitis & $7(7.2)$ \\
Grade D oesophagitis & $0(0)$ \\
Others & $2(2)$ \\
Results of gastric endoscopy & $3(3.1)$ \\
Normal & $0(0)$ \\
Atrophy gastritis & $2(2.1)$ \\
Gastritis with gastric lesion & $4(4.1)$ \\
Gastritis with gastric ulcer & $1(1)$ \\
Gastric lesion with gastric ulcer & $1(1)$ \\
Gastric ulcer & $73(75.3)$ \\
Results of duodenal endoscopy & $15(15.4)$ \\
Normal & $2(2.1)$ \\
Duodenitis & $2(2.1)$ \\
Duodenitis with duodenal erosion & $1(1)$ \\
Duodenitis with duodenal ulcer & $3(3.1)$ \\
Duodenal erosion with duodenal ulcer & $1(1)$ \\
Duodenal ulcer & \\
Duodenal mass &
\end{tabular}

\begin{tabular}{ll}
\hline Location H. pylori was found & \\
Antrum & $3(3.1)$ \\
Fundus & $3(3.1)$ \\
Antrum and fundus & $1(1)$ \\
Degree of antrum inflammation & $4(4.1)$ \\
No data & $70(72.2)$ \\
Mild & $21(21.6)$ \\
Moderate & $2(2.1)$ \\
Severe & \\
Degree of antrum atrophy & $4(4.1)$ \\
No data & $55(56.7)$ \\
Non-Atrophy & $29(29.9)$ \\
Mild & $9(9.3)$ \\
Moderate & $0(0)$ \\
Hard & \\
Degree of corpus inflammation & $11(11.3)$ \\
No data & $68(70.1)$ \\
Mild & $1(1)$ \\
Mild-moderate & $16(16.5)$ \\
Moderate & $1(1)$ \\
Hard & $11(11.3)$ \\
Degree of corpus atrophy & $77(79.4)$ \\
No data & $8(8.2)$ \\
Non-atrophy & $0(0)$ \\
Mild & $1(1)$ \\
Moderate & \\
Hard &
\end{tabular}

Prevalence of $H$. pylori infection based on histopathology examination was $7.2 \%$. From seven positive results in histopathology examination, four samples were Helocitec positive. The sensitivity and specificity of Helicotec was $57.1 \%$ and $98.9 \%$. The positive predictive value and negative predictive value were $80 \%$ and $96.7 \%$.

Table 3. Sensitivity, specificity, positive predictive (PPV), negative predictive values (NPV), and likelihood ratio (LR)

\begin{tabular}{cccccc}
\hline Sensitivity & Specificity & PPV & NPV & LR + & LR - \\
\hline $57.1 \%$ & $98.9 \%$ & $80 \%$ & $96.7 \%$ & 51.9 & 0.43 \\
\hline
\end{tabular}

\section{DISCUSSION}

H.pylori colonising in gastric mucosa produce urease enzyme in a significant amount. This becomes the basis of various diagnostic test to detect H.pylori. Rapid urease test is an indirect $H$. pylori test detection using detection of urease concentration in gastric mucosa. Rapid urease test has a superiority which relates to its ability to detect active $H$. pylori infection compared to serologic examination. Additionally, rapid urease test can be performed quickly and efficiently compared to histopathology examination. Results of this study showed that the prevalence of $H$. pylori infection was $7.2 \%$. This number was slightly lower compared to the study performed in Jakarta in 2006, which was $8 \%{ }^{6}$

The sensitivity, specificity, positive predictive value, and negative predictive value were $57.1 \%$, $98.9 \%, 80 \%$, and $96.7 \%$. The sensitivity of this Helicotec test was different to the results of rapid urease test using Pronto Dry in Jakarta which were 95.7\% ${ }^{6}$ Nonetheless, the sensitivity rate of Helicotec test was not so different with the results of the study using Pronto Dry in Indonesia which were 69.6\%, with 
better positive predictive value compared to Pronto Dry which were $66.1 \%{ }^{6}$

Results of rapid urea test can be influenced by atrophic gastric mucosa which causes the number of microorganisms to be low, thus giving out false negative results. False negative results may also be found when patients consume PPI prior to the examination and have intestinal metaplasia. False positive results might be acquired if there was other microorganism producing urease in adequate amount, usually caused by specimen was left for too long ( $>24$ hours).The sensitivity and specificity of rapid urease test might be increased using bigger biopsy forceps (jumbo forceps). ${ }^{7}$

Interpretation of rapid urease test also need to consider pre-test probability value of each case. ${ }^{8}$ For example, in a case with duodenal ulcer, negative result in rapid urease test is better confirmed with histopathological examination. Additionally, rapid urease test should not be used as a single test in evaluating results of $H$. pylori eradication because its sensitivity is not $100 \% .{ }^{9,10}$

Rapid urease test using Helicotec has a good specificity, although the sensitivity was low. This test may give result in relatively short time with lower cost.

\section{CONCLUSION}

Rapid urease examination using Helicotec is one of H. pylori diagnostic tools that is good enough to diagnose faster and cheaper. Interpretation of rapid urease test also need to consider clinical condition of patients who are tested.

\section{REFERENCES}

1. Chiba N, Van Zanten SJOV, Sinclair P, Ferguson RA, Escobedo S, Grace E. Treating Helicobacter pylori infection in primary care patients with uninvestigated dyspepsia: the Canadian adult dyspepsia empiric treatment-Helicobacter pylori positive (CADET-Hp) randomised controlled trial. BMJ (Clinical research ed). 2002;324:1012-6.

2. Santos IS, Boccio J, Santos AS, Valle NCJ, Halal CS, Bachilli $\mathrm{MC}$, et al. Prevalence of Helicobacter pylori infection and associated factors among adults in Southern Brazil: a population-based cross-sectional study. BMC public health. 2005;5:118.

3. Cheng H, Hu F, Zhang L, Yang G, Ma J, Hu J, et al. Prevalence of Helicobacter pylori infection and identification of risk factors in rural and urban Beijing, China. Helicobacter 2009;14:128-33.

4. Talley NJ, Vakil N. Guidelines for the management of dyspepsia. Am J Gastroenterol 2005;100:2324-37.

5. McColl KE, El-Nujumi A, Murray L, El-Omar E, Gillen D, Dickson A, et al. The Helicobacter pylori breath test: a surrogate marker for peptic ulcer disease in dyspeptic patients. Gut 1997;40:302-6.

6. Syam AF, Abdullah M, Rani AA, Nurdjanah S, Adi P, Djumhana A, et al. Evaluation of the use of rapid urease test: Pronto Dry to detect $H$ pylori in patients with dyspepsia in several cities in Indonesia. World J Gastroenterol 2006;12: 6216-8.

7. Yousfi MM, El-Zimaity HM, Cole RA, Genta RM, Graham DY. Detection of Helicobacter pylori by rapid urease tests: is biopsy size a critical variable? Gastrointest Endosc 1996;43:222-4

8. Vecchio TJ. Predictive value of a single diagnostic test in unselected populations. N Engl J Med 1966;274:1171-3

9. Attumi TA, Graham DY. Follow-up testing after treatment of Helicobacter pylori infections: cautions, caveats, and recommendations. Clin Gastroenterol Hepatol 2011;9:373-5.

10. Malfertheiner P, Megraud F, O'Morain CA, Atherton J, Axon AT, Bazzoli F, et al. Management of Helicobacter pylori infection--the Maastricht IV/ Florence Consensus Report. Gut 2012;61:646-64. 